\title{
Employing Language Typology for Teaching Biblical Hebrew: A Test Case in Cantonese- Chinese
}

\author{
KeVin ChaU (University OF THE Free State)
}

\begin{abstract}
This article follows upon Jacobus A. Naudé and Cynthia L. MillerNaudé's "A New Biblical Teaching Grammar for African Bible Translators" (OTE 24/3 [2011]), which presented a paradigm shift for teaching Biblical Hebrew to non-native English speakers. They argued that grammars and lecturers can confuse students by presenting Biblical Hebrew through the viewpoint of English (and other Indo-European languages) in which elements of the English grammar may fundamentally differ from the grammars of the students' native languages. They proposed that such problems can be avoided or mitigated by employing language typology (how languages and components of language are classified according to their formal features). This article utilizes Cantonese-Chinese as a test case for demonstrating how language typology may be specifically applied in the instruction of Biblical Hebrew to students from one particular language. It illustrates how employing language typology addresses the wide range of grammatical concepts in Biblical Hebrew, specifically the points of (non)correspondence between Biblical Hebrew versus Cantonese and English.
\end{abstract}

KEY WORDS: Biblical Hebrew Language; Biblical Hebrew Linguistics; Language typology; Cantonese-Chinese.

\section{A INTRODUCTION}

Some years ago in my first experience with teaching Biblical Hebrew (BH) to non-native English speakers (in this case Kenyan), I was a bit perplexed as to why my students were struggling to understand the definite article in BH. This problem is discussed in detail in Jacobus A. Naudé and Cynthia L. MillerNaudé's "A New Biblical Teaching Grammar for African Bible Translators: A Typological Approach" on the basis of the experience of Naudé in teaching BH to Sesotho students in South Africa. ${ }^{1}$ There is an inherent disconnect for many

* Article submitted: 30/11/2016; peer-reviewed: 30/01/2017; accepted: 20/02/2017. To cite: Kevin Chau, "Employing Language Typology for Teaching Biblical Hebrew: A Test Case in Cantonese-Chinese," Old Testament Essays 30 (1) 2017: 56-76. Doi: http://dx.doi.org/10.17159/2312-3621/2017/v30n1a5 
African students because their native languages lack a morpheme (the smallest unit of speech that has meaning) for the definite article. ${ }^{2}$ After speaking with my students, they explained how they use a demonstrative pronoun in place of the definite article. Thus for example in their native languages, they do not say "the dog" but rather "this dog." For native English-speaking students, learning the definite article in $\mathrm{BH}$ is quite easy because English (and other European languages) is similar to BH in how both languages have a definite article, but my Kenyan students had difficulty since their languages lack a corresponding morpheme to the definite articles in English and BH. After some more discussion with one of my students, I was shocked in realizing that his native language of Kiitharaka (a Bantu language) is similar to Cantonese-Chinese (which I speak). ${ }^{3}$ Both languages lack a definite article and use demonstratives to convey definiteness. Thus for example, if one wants to refer to a specific entity like "the house" in Cantonese, one would use a demonstrative:

$$
\begin{array}{lll}
\text { nī gāan } & \overline{\mathrm{uk}}{ }^{4} \\
\text { this } & \mathrm{CL} & \text { house } \\
\text { this house } &
\end{array}
$$

I recognized that many of my overseas-born relatives have the same problem in utilizing and processing English definite articles on account of the inherent disconnect. Hence, my grandmother would not use English definite articles in instances when a definite article was appropriate:

(2) Eat. *Noodles are good. (The specific noodles at the table.)

1 Jacobus A. Naudé and Cynthia L. Miller-Naudé, "A New Biblical Teaching Grammar for African Bible Translators: A Typological Approach," OTE 24 (2011): 690-707.

2 While all languages possess linguistic strategies to convey definiteness, not all languages possess a morpheme equivalent to the definite articles as in English, $\mathrm{BH}$, and many European languages; Matthew S. Dryer, "Definite Articles," in The World Atlas of Language Structures Online, ed. Matthew S. Dryer and Martin Haspelmath (Leipzig: Max Planck Institute for Evolutionary Anthropology, 2013), http://wals.info/chapter/37.

3 Cantonese-Chinese (prominent in southern China and Hong Kong) is not to be confused with Mandarin-Chinese, China's official language. From here onward, the labels "Cantonese" and "Mandarin" will be used for simplicity.

4 Unless noted otherwise, the Cantonese examples are mine. CL denotes noun classifier, which sorts nouns into different semantic classes. For example, the Cantonese CL tiuh is used for thin and long items, like snakes and noodles. In Cantonese, they are often syntactically necessary when a demonstrative is used attributively with a noun. Cf. Stephen Matthews and Virginia Yip, Cantonese: A Comprehensive Grammar (London: Routledge, 2010), 92-94. The CL is not to be confused with noun class morphemes (as in Kiitharaka) that are used for agreement between verbs and arguments (e.g., subject, object, etc.). Cf. Lindsay Whaley, Introduction to Typology: The Unity and Diversity of Language (Thousand Oaks: Sage Publications, 1997), 166. 
I recognised that by not considering my own knowledge of Cantonese, a non-western language and how languages can differ widely, I unwittingly became an unsympathetic teacher for my African, non-native English-speaking students. As a result, when I work with students that are non-native English speakers (or native English speakers that know another language), I take the time to inquire about points of (non)contact between the non-English languages and $\mathrm{BH}$ in order to present $\mathrm{BH}$ in more familiar and relatable linguistic contexts.

In 2011 Jacobus A. Naudé and Cynthia L. Miller-Naudé published "A New Biblical Teaching Grammar for African Bible Translators: A Typological Approach," which detailed their plans in producing a new Hebrew grammar that is centred upon language typology. ${ }^{5}$ Their article addressed the exact type of language issues that was just shared and that often arise when students from non-Indo-European languages learn $\mathrm{BH}$. In this article, it is unnecessary to review in detail what was already so well explained and introduced in that article, but a brief overview is helpful. First, they argued that teaching grammars are most successful when they can describe the taught language in terms of the grammar of the student's native language. ${ }^{6}$ They proposed that a fundamental problem in teaching Hebrew to non-native English speakers is that these English-based Hebrew grammars present the Hebrew language through the "lenses" of English (and other Indo-European languages). They demonstrated how on occasion certain facets of the Hebrew language are more similar to an African student's native language, and when explaining the Hebrew through English grammar equivalents, students can become confused. For example, they showed whereas Hebrew and Bantu languages are both aspect-prominent languages, English is a tense-prominent language. For students from Bantu languages, English-based teaching grammars can be potentially confusing because they "translate" the Hebrew aspect-prominent verbal system in terms of tense when, in fact, Bantu language speakers will have a natural affinity for understanding the aspectual system of the $\mathrm{BH}$ verbal system. ${ }^{7}$ Second, they proposed that by using language typology, teachers may better tailor their teaching regardless of which native languages the students speak by showing the typological differences and affinities between their native language and $\mathrm{BH}^{8}$ Language typology is the linguistic study of how languages and components of language (e.g., possessive constructions, verbal agreement, subordinate clauses, etc.) are categorized and classified according

5 Naudé and Miller-Naudé, “A New Biblical,” 690-707.

6 Naudé and Miller-Naudé, "A New Biblical," 691-92.

7 Naudé and Miller-Naudé, "A New Biblical," 692, 696.

8 Naudé and Miller-Naudé, "A New Biblical," 695-97. 
to the formal features of language (i.e., the "chunks" of information in a language that are used to convey meaning and information). ${ }^{9}$

On account of my bilingual background in Cantonese-Chinese, I present this article as a follow-up to Naudé and Miller-Naudé's seminal and paradigmshifting work by surveying the typology of Cantonese in relation to $\mathrm{BH}$ and English. Admittedly, the majority of this article's readers are not likely to know Cantonese or be concerned with the teaching of BH to Cantonese speakers. It is this typological comparison of $\mathrm{BH}$ to Cantonese (which is typologically unrelated to $\mathrm{BH}$, English, and African languages) that demonstrates how language typology can be used to specifically teach non-native English speakers from one particular language. Thus, the following typological comparisons of $\mathrm{BH}$ to Cantonese and English are still quite relevant to $\mathrm{BH}$ teachers and translators for African language speakers and may even reveal affinities between Cantonese and other African languages that can additionally profit $\mathrm{BH}$ instruction and translation. However, before exploring the typology of Cantonese for the purpose of teaching Biblical Hebrew, I wish to provide an example of how language typology is applied to subjects and objects.

\section{B LANGUAGE TYPOLOGY EXEMPLIFIED}

All languages possess subjects and objects; however, how a given language communicates that a given word is a subject or object (i.e., grammatical relations) varies. Language typologists have classified how languages designate subjects and objects according to five major strategies: word order, verbal agreement, grammatical case (dependent marking), head marking, and a combination of the aforementioned. ${ }^{10}$

Both English and Cantonese use word order: subjects and objects are determined through the standardized word order of SVO (subject, verb, object).

(3) The girl drives a car.

(4) Go jaí sihk yú.

CL boy eats fish

The boy eats fish.

In other words, Cantonese and English speakers can identify the subjects and objects in a sentence on the basis of whether these constituents come before or after the verb. ${ }^{11}$

9 Whaley, Introduction to Typology, 7, 14.

10 Whaley, Introduction to Typology, 152-55, 164-66.

11 Though English and Cantonese can both form constructions in which the object is fronted (e.g., Fish, I do not like), Whaley notes that these atypical OSV constructions are considered marked constructions on account of its phonological stress (italicised) 
BH uses a grammatical agreement system in which the subject's morphology agrees with the verb's morphology in person, gender, and number. ${ }^{12}$ And if the subject and object possess the same person, gender, and number, $\mathrm{BH}$ also has an accusative marker ( $e t$ ) that can further differentiate subjects and objects.

(5) Joshua 6:12

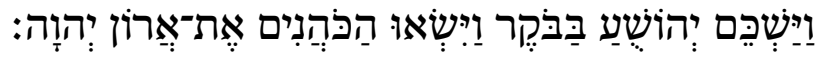

Then Joshua (3-Masc Sg) rose early (3-Masc Sg) in the morning, and the priests (3-Masc Pl) lifted up (3-Masc Pl) the ark of the LORD (3-Masc Sg).

Koine Greek uses a grammatical case system in which subjects (nominative case) are differentiated from objects (accusative case) through the use of case morphology on nouns and definite articles. ${ }^{13}$

(6)

\begin{tabular}{|c|c|c|}
\hline 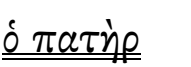 & $\phi ı \lambda \varepsilon \tilde{\imath}$ & Tòv vióv \\
\hline The father & loves & the son. \\
\hline oviós & $\phi ı \lambda \varepsilon \tilde{\imath}$ & $\underline{\tau} \dot{\partial} \nu \pi \alpha \tau \varepsilon \dot{p} \rho \alpha$ \\
\hline The son & loves & the father. \\
\hline
\end{tabular}

The nouns "father" and "son" have different morphological endings depending on whether a given noun is subject or object (see the corresponding underlined forms). Although Koine Greek is a case language, it also utilizes subject-verb agreement, but it differs from BH's subject-verb agreement system in that it only uses agreement for grammatical person and number (and not gender).

Tzutujil (Mayan; Guatemala) is an example of a head marking system in that the verb (verbal head) solely carries all the morphology for designating the grammatical relationships for the verbal dependents (e.g., subject, object, dative, etc.). In this following example, the superscripts (a-b) mark the verbal dependents (subject and object) and the respective verbal prefixes that index them.

and prominent usage in contrastive construction (e.g., I like pork, but fish, I hate). Cf. Whaley, Introduction to Typology, 80-81.

12 Languages differ as to which categories are used for verbal agreement; for example, Spanish and Greek only use person and number.

13 More specifically, case systems such as Koine Greek are labelled as a dependent marking system because the syntactic dependents carry the sole markings (morphology) that communicate which nouns are subject and object to the syntactic head (the verb). 
Chau, "Employing Language Typology,” OTE 30/1 (2017): 56-76

\begin{tabular}{|c|c|c|c|c|}
\hline (7) & $\begin{array}{l}\text { jar aak'aalaa7 } \\
\text { the boys }{ }^{\text {b }} \\
\text { ja jaay. }{ }^{14} \\
\text { the house } \\
\text { The boys threw }\end{array}$ & $\begin{array}{ll}x-\varnothing-k e e-k ' a q & \text { aab'aj } \\
\text { comp-3sg }^{\text {a }}-3 \text { pl }^{\text {b-throw }} & \text { rock }^{\text {a }}\end{array}$ & $\begin{array}{l}\text { pa } \\
\text { on }\end{array}$ & $\begin{array}{l}\text { rwi7 } \\
\text { top.of }\end{array}$ \\
\hline
\end{tabular}

Thus, the two morphemes $x-\varnothing$ together index the object (complement) as a 3rd singular noun (rock[s]) and the kee morpheme indexes the subject as a 3rd plural noun (boys). ${ }^{15}$

This survey of the different ways that languages encode subjects and objects can be used to determine the potential difficulties that students from a given language (assuming they only know their native languages) may face when learning the Hebrew verb. Thus for example, Hebrew, Koine Greek and Tzutujil all use different strategies for encoding subjects and objects, but all these languages share the feature in which subjects are determined by some means of cross-referencing grammatical person and number between the verb and subject. As a result, Tzutujil and hypothetical Koine Greek speakers presumably will have an easier time comprehending subject-verbal agreement in BH on account of their languages' similarity. However, because Cantonese and English both use standard word order (as opposed to a cross-referencing system of person, gender, and number), these native speakers will be more unfamiliar with the subject-verbal agreement system in $\mathrm{BH}$ and potentially need more time and instruction for this particular language feature.

\section{TEACHING HEBREW TO CANTONESE SPEAKERS TYPOLOGICAL APPROACH)}

In the rest of my paper, I give an overview for two main ways in which language typology can be utilized in teaching $\mathrm{BH}$ with Cantonese as the sample language with the assumption that the teaching grammars are written in English and from an English language perspective: (1) when $\mathrm{BH}$ and Cantonese are typologically similar but dissimilar to English and (2) when $\mathrm{BH}$ and English are typologically similar but dissimilar to Cantonese. With examples from these two categories, I illustrate how instructors can better cater to the needs of students by keeping language typology in mind in order to find points of (non)correspondence among English, BH, and a student's native language.

14 Adapted from Jon P. Dayley, Tzutujil Grammar, UCPL 107 (Berkeley: University of California Press, 1985), 282.

15 The noun for "rock" is a collective singular; that is, it is morphologically singular but semantically taken as a plural. This is comparable to how "fish" is used in English when "fish" can refer to a plurality of fish. 


\section{Bypassing the English: When Biblical Hebrew and Cantonese are Typologically Similar but Dissimilar to English}

In many instances, a given native language and $\mathrm{BH}$ are typologically similar in terms of a particular feature of the language and the same feature in English will be dissimilar. As a result, instructors will do well to teach the particular language feature in $\mathrm{BH}$ by concentrating on the similarities between the native language and $\mathrm{BH}$ and not worrying about the lack of correspondence with English. The following examples from Cantonese examine polar questions and verbal aspect.

\section{1a Polar Questions}

All languages use polar questions, which require a positive or negative response. In English, they are often referred to as a yes-no question. In terms of typology, languages have three strategies for constructing responses to these polar questions: (1) yes-no system, (2) agree-disagree system, and (3) echo system. ${ }^{16}$ For the yes-no system, English is a prime example in which the positive and negative particles "yes" and "no" are used for positive and negative responses.

(8) Question: Did you eat the cake?

Positive Answer: $\quad$ Yes (= I did)

Negative Answer: No (= I did not)

English speakers may use just these particles or they may use the particles in conjunction with the appropriate (negative/positive) answer. In cases where the particle is solely used, the particle is elliptical for the complete response. For the agree-disagree system, the responder answers in the positive by agreeing and in the negative by disagreeing. The following example from Japanese illustrates: ${ }^{17}$

(9) Question: Kyoo-wa atu-i des-u ne? It's hot today, isn't it? Answer: Hai (soo des-u ne) Right (it's hot today) Iie (atuku-wa arimasen) Wrong (it isn't hot today)

Similar to the yes-no system, the echo system utilizes a negative morpheme for negative responses, but it differs in its lack of a specific

16 Jerrold M. Sadock and Arnold M. Zwicky, "Speech Act Distinction in Syntax," in Clause Structure, ed. Timothy Shopen, vol. 1 of Language Typology and Syntactic Description, ed. Timothy Shopen, 1st ed. (Cambridge: Cambridge Univ. Press, 1985), 189-91. For the application of the typology of yes-no questions to BH, see Cynthia L. Miller, "Linguistics," DOTHB, 660-61.

17 Emily Pope, "Questions and Answers in English," (PhD thesis, Massachusetts Institute of Technology, 1972), 193 
Chau, "Employing Language Typology," OTE 30/1 (2017): 56-76 63

morpheme that denotes a positive response. Cantonese and $\mathrm{BH}$ examples illustrate.

$\begin{array}{ll}\text { Question: } & \begin{array}{l}\text { Léih gin-gwo kéiuh meih a } \\ \text { You see-EXP her/him not-yet Particle }\end{array} \\ & \text { Have you met (lit. "see") her/him before? } \\ \text { Answer: } & \begin{array}{l}\text { Gin-gwo la // Meih a } \\ \text { see-EXP Particle not-yet Particle } \\ \text { I have met (Yes). // No }\end{array}\end{array}$

(11) Judges 12:5-6a

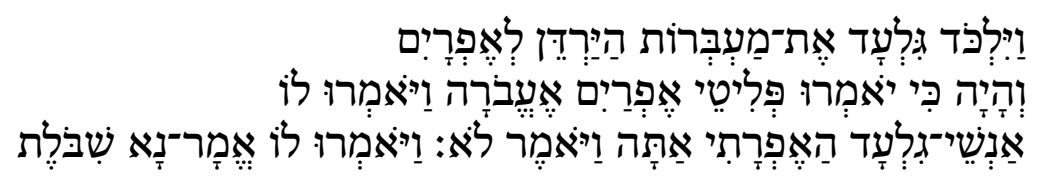

Then Gilead captured the fjords of the Jordan against the Ephraimites. When one of the fugitives of Ephraim said, "Let me cross," the men of Gilead said to him, "Are you an Ephraimite?" When he said, "No," they said to him, "Say Shibboleth,"

(12) 1 Samuel 23:12

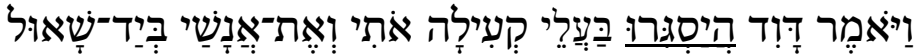

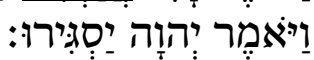

Then David said, "Will the lords of Keilah surrender me and my men into the hand of Saul?" The LORD said, "They will surrender (you)."

Unlike the yes-no and agree-disagree systems, both Hebrew and Cantonese can only answer in the positive by echoing a portion of the question, usually the verb. ${ }^{19}$ In examples (10) and (12), the verbs (bolded or underlined) are repeated to form the positive answers. And with the negative answers, a negative morpheme is used and no echoing is necessary (though it can occur). Thus on a typological level, all languages utilize some form of a negative for negative responses, ${ }^{20}$ but only the echo system lacks an analogous positive morpheme. Because

18 EXP denotes experiential aspect; PRT denotes particle. The first person subject pronoun in the response is not necessary, though it can be used for an emphatic response. Example adapted from Matthews and Yip, Cantonese, 319.

19 Edward L. Greenstein, "The Syntax of Saying 'Yes' in Biblical Hebrew," JANESCU 19 (1989): 51-59.

20 For more concerning the typology of negative constructions, see Östen Dahl, “Typology of Sentence Negation” Ling 17 (1979): 79-106. 
BH and Cantonese both utilize an echo system, Cantonese students will have very little trouble in understanding how one may answer a polar question in the positive without a positive morpheme like "yes" in English. Thus in teaching how $\mathrm{BH}$ forms polar questions and their responses, teachers for Cantonese speakers will better cater to their students by concentrating on the inherent similarities between Cantonese and $\mathrm{BH}$ and by de-emphasizing how English polar questions work differently, especially in its usage of a positive particle which is not present in Cantonese and $\mathrm{BH}$.

\section{1b Verbal Aspect}

The second example surveys the similarities between Cantonese and $\mathrm{BH}$ verbal systems, specifically how both are aspect-prominent languages. In terms of typology, all languages can convey the concepts of tense (past, present, future), aspect (e.g., perfective vs. imperfective), and mood (e.g., real vs. irreal; indicative, subjunctive, etc.). But the verbal forms for specifically denoting tense, aspect, and mood will have different levels of prominence for a given language. Languages often have their verbal forms prominently feature one of these three elements. ${ }^{21}$ For example, Burmese lacks specific verbal morphology for designating tense. Burmese instead uses modal verbal suffixes: realis mood for past tense and irrealis mood for future tense. ${ }^{22}$ Cantonese (an aspectprominent language) similarly has no verbal morphology specifically designated for tense and instead uses time adverbs (e.g., tomorrow, yesterday, etc.) and context to convey temporality. While the $\mathrm{BH}$ verbal system is a subject of extensive research, most scholars agree that $\mathrm{BH}$ is an aspectprominent language and this is most clearly seen in the opposition of the perfective (qatal/suffix conjugation) and imperfective (yiqtol/prefix conjugation) verbal forms. ${ }^{23}$ Like many African languages, Cantonese is also

21 Thus for example with $\mathrm{BH}$, Cook argues that $\mathrm{BH}$ is aspect-prominent in its verbal grammatical forms (the opposition of qatal [perfective] to yiqtol [imperfective]), but this aspect-prominence does not preclude $\mathrm{BH}$ from possessing grammatical forms for specifically denoting tense (e.g., Cook identifies wayyiqtol as a grammatically marked past tense form); John Cook, Time and the Biblical Hebrew Verb: The Expression of Tense, Aspect, and Modality in Biblical Hebrew, LSAWS 7 (Winona Lake: Eisenbrauns, 2012), 260.

22 Using the irrealis mood for denoting future tense makes sense since future events have not yet occurred or only have a chance to occur; Whaley, Introduction to Typology, 206.

23 Christo H. J. van der Merwe, Jackie Naudé, and Jan H. Kroeze, A Biblical Hebrew Reference Grammar (Sheffield: Sheffield Academic Press, 2006), §19.1.3; Cook, Time, 200; Bruce K. Waltke and Michael P. O'Connor, An Introduction to Biblical Hebrew Syntax (Winona Lake: Eisenbrauns, 1990), §30.1a. Joosten differs markedly from the aforementioned in his identification of the yiqtol as primarily denoting irreal modality; Jan Joosten, The Verbal System of Biblical Hebrew: A New Synthesis 
an aspect-prominent language, which uses verbal suffixes to denote aspectual meanings. Thus in contrast to teaching native English speakers in the context of their tense-prominent language, explaining the $\mathrm{BH}$ aspectual system to Cantonese speakers is far easier on account of how many of the $\mathrm{BH}$ aspectual meanings correspond nicely with the Cantonese aspectual suffixes.

Since both languages are aspect-prominent, it is no surprise that both languages have perfective and imperfective grammatical forms. ${ }^{24}$ The $\mathrm{BH}$ suffix conjugation (perfective) corresponds with the Cantonese perfective.

(13) Cantonese Perfective

\begin{tabular}{|c|c|}
\hline Ngóh yíhgīng & sāan-jó \\
\hline already & shut-Perfective \\
\hline
\end{tabular}

(14) Genesis 20:10 (Suffix Conjugation/Perfective)

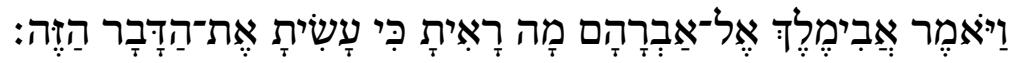

And Abimelek said to Abraham, "What have you seen that you have done this thing?"

While $\mathrm{BH}$ has the prefix conjugation as the grammatical form for denoting imperfective aspect, ${ }^{26}$ Cantonese has three verbal suffixes for denoting different nuances of the imperfective (unbounded aspect): progressive, continuous, and habitual. ${ }^{27}$ The semantics of these Cantonese imperfective suffixes are also present in the $\mathrm{BH}$ imperfective prefix conjugation. ${ }^{28}$ At first glance, this non-correspondence may seem to be a difficulty, but it is

Elaborated on the Basis of Classical Prose, JBS 10 (Jerusalem: Simor, Ltd., 2012), 18-19, 31-33, 96-97, 261-87.

24 Cantonese also has the verbal suffixes for denoting experiential ( $g w o$ ) and delimitative (háh) aspects. The delimitative is used for situations that denote a short unspecified period of time. The experiential is comparable to the perfect in English. It differs crucially from the Cantonese perfective in that the experiential is used to denote perfective situations that no longer apply. For example, if a person, who no longer resides in the US, is asked how long he lived in the US, the experiential (gwo) is used. If a person that is still residing in the US is asked the same question, then the perfective (jó) is used; Matthew and Yip, Cantonese, 206-9.

25 Example adapted from Matthews and Yip, Cantonese, 206.

26 This prefix form yiqtol derives historically from the yaqtulu long form and is distinct from the yaqtul short form that is used for the jussive and wayyiqtol.

27 Hilary Chappell, "On So Called Empty Particles in Yue-Guangzhou (Cantonese): A Study of Aspect," LTWPL 2 (1989): 97, 106.

28 Cook however categorizes the habitual for yiqtol as belonging to the domain of mood. Specifically, the BH habitual is a modal because a habitual event, though certain in its occurrence, is uncertain in its frequency and timing; Cook, Time, 248. 
welcomed since the Cantonese aspectual suffixes allow teachers to show how the various imperfective meanings of the prefix form are specifically realized in the various Cantonese aspectual suffixes for which students have native intuition. In other words, the variation within the wider typological alignment of how the two languages are aspect-prominent provides a pedagogically "workable space" for students to explore the BH imperfective aspect within the familiar confines of their native understandings of imperfective aspect.

In example (15), the prefix verb "to be wise" (חכם) is semantically stative and also morphologically stative because it is a strong verb with the yiqtalu historical form in which the qamets gadol (pausal form) reflects the original /a/ vowel of this historical form. ${ }^{29} \mathrm{With} \mathrm{BH}$ strong verbs, the active verb generally derives from the historical yaqtulu, which is realized as yiqtol (yišpot in [16]). ${ }^{30}$

(15) Proverbs 20:1 (Stative Prefix Conjugation)

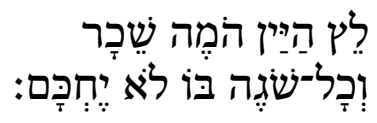

Wine is a mocker, liquor is a rager, and any who errs with it is not wise.

Psalm 82:1b-c (Active Prefix Conjugation)

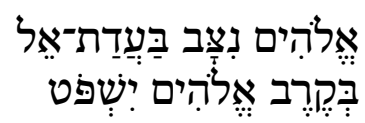

God takes his place in the divine council.

In the midst of divine beings he is judging.

In $\mathrm{BH}$ this morphological distinction between stative and active verbs is not absolute, and most importantly, both the stative and active senses in the imperfective still employ the same prefix conjugation. Moreover, many $\mathrm{BH}$ students will not even recognize this distinction semantically nor in the vocalization. However, Cantonese speakers will have little difficulty in understanding how an imperfective may have active and stative senses since in their native language, the stative and active senses of the $\mathrm{BH}$ imperfective are comparable respectively to the Cantonese aspectual forms of the imperfective continuous and imperfective progressive.

29 Waltke and O'Connor, Biblical Hebrew Syntax, $\$ 22.3 \mathrm{k}, 31.3 \mathrm{c}$.

30 A minority of verb do not hold to this generalization; for example "to learn" (ילמַמד/לָמַד); see Waltke and O’Connor, Biblical Hebrew Syntax, §22.31. 
Chau, "Employing Language Typology," OTE 30/1 (2017): 56-76

(17) Cantonese Imperfective Continuous (verb + jyuh)

$\mathrm{Ga}$ chē jó-jyuh yàhndeih. ${ }^{31}$

$\mathrm{CL}$ car block-Continuous people

The car is blocking people.

(18) Cantonese Imperfective Progressive (verb + gan)

Kéuih wan-gan sīgēi.

you seek-Progressive driver

$\mathrm{S} / \mathrm{he}$ is seeking a driver.

The Cantonese imperfective continuous and imperfective progressive are differentiated in their situational aspect, specifically with regard to (+/-) stages (discernible differences in the course of the action/event). ${ }^{32}$ The imperfective continuous is (-) stages but the imperfective progressive is (+) stages. Thus in example (17), the car is construed as parked and in a constant (continuous) state of blocking potential pedestrians, but in example (18) the event of searching is understood to have different phases to finding a driver (e.g., one can be at a stage that is closer or not closer to finding a driver). Whereas the $\mathrm{BH}$ verbal system does not have robust morphology in the prefix imperfective for differentiating the stative and active verbs, the differentiation in Cantonese is a welcome difference that teachers can exploit to additionally explain the nuances of the $\mathrm{BH}$ prefix imperfective in terms of situation aspect (e.g., stative vs. active verbs).

Whereas the $\mathrm{BH}$ prefix conjugation in itself only denotes the imperfective aspect and the specific nuance of the habitual imperfective is derived semantically and contextually (i.e., not from any specific verbal morphology), Cantonese employs a specific aspectual suffix to denote an imperfective habitual.

(19) Job 1:5i (BH Prefix Imperfective Habitual)

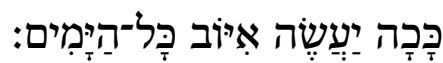

Thus, Job would do all the days (i.e., offer sacrifices for his children).

(20) Cantonese Imperfective Habitual (verb + hōi)

Kéuih yíchìhn jā-hōi Bēnsí ge. ${ }^{33}$

She/he before do-Habitual (Mercedes) Benz Particle

She used to drive a Mercedes.

31 Example from Matthews and Yip, Cantonese, 203.

32 For more on how these parameters determine situational aspect in $\mathrm{BH}$, see Cook, Time, 58-62.

33 Example from Matthews and Yip, Cantonese, 210. 
The $\mathrm{BH}$ verbal system, as most instructors can attest, is one of the more difficult elements to teach. The verbal system's numerous conjugations and stem formations for beginning students may seem to form a dizzying array of endless forms. The semantics of the verbal system prove no easier for students, but for Cantonese speakers, some of this complexity, specifically the aspectual elements, can be overcome by exploring how BH and Cantonese share a typological similarity in their aspect-prominent verbal systems, especially in how each language conveys perfective and imperfective aspectual senses.

\section{Heading off Mistakes: When Biblical Hebrew and English are Typologically Similar but Dissimilar to Cantonese}

The following are examples in which the English and $\mathrm{BH}$ are typologically similar, but the Cantonese is different. These are cases in which native-English speakers easily understand the grammatical concept since teachers can say "this is just like English" or "this is similar to English," but for Cantonese speakers, the concepts are quite unfamiliar, and teachers must consider the key differences. These cases also reflect how BH grammars written from an English perspective may not address potential problems for Cantonese speakers since the English and $\mathrm{BH}$ grammatical structures are typologically similar. All of the following examples are drawn from the syntactic typology of subordinate clauses.

\section{2a Subordinators and their Relationship to the Clause}

The first example involves the typology of subordinators, specifically the positions in which the subordinator may appear. In general, subordinate clauses are marked by a subordinator (separate word), a special verbal form, or an affix to the verb; in certain languages, the subordinate clauses also display a special word order. ${ }^{34}$ These subordinators may appear in the initial, internal, or final positions of the subordinate clause, and a language is not necessarily restricted to the use of one position for its subordinators. ${ }^{35}$ English and $\mathrm{BH}$ use initial subordinators.

(21) When it rains, I wear a coat. (Initial Temporal Subordinator)

(22) Proverbs 25:21a (Initial Conditional Subordinator ['im])

\footnotetext{
34 Whaley, Introduction to Typology, 249-55; Sandra A. Thompson, Robert E. Longacre, and Shin Ja J. Hwang, "Adverbial Clauses" in Complex Constructions, ed. Timothy Shopen, vol. 2 of Language Typology and Syntactic Description, ed. Timothy Shopen, 2nd ed. (Cambridge: Cambridge University Press, 2007), 238-43.

35 Matthew S. Dryer, "Order of Adverbial Subordinator and Clause," The World Atlas of Language Structures Online, ed. Matthew S. Dryer and Martin Haspelmath (Leipzig: Max Planck Institute for Evolutionary Anthropology), http://wals.info/chapter/94.
} 
Chau, "Employing Language Typology,” OTE 30/1 (2017): 56-76 69

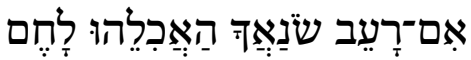

If the one who hates you is hungry, give him bread to eat.

Cantonese is one of the less frequently occurring languages in which its subordinators display a mixed usage. ${ }^{36}$

(23) Final Temporal Subordinator

Kéuih héi-sān jīhauh jauh tái boují. ${ }^{37}$

S/he rises after then reads newspaper

After he gets up (lit. "rises"), he reads the newspaper.

(24) Initial Conditional Subordinator

Yùhgwó yáuh sìhgaan jauh hóyíh heui taí-háh ${ }^{38}$

If have time then can go look-Delimitative

If there is time, we can go and take a look.

In the contrastive Cantonese examples of (23) and (24), the temporal clause uses a final temporal subordinator, but the conditional clause uses an initial subordinator. With English speaking students, teachers in general need not worry about students reading a Hebrew subordinator "backwards." But with Cantonese speakers, since reading a final temporal subordinator (i.e., at the end of the subordinate clause) is natural, a student may accidentally read a temporal subordinator in Hebrew as relating to a preceding clause.

(25) Josh 3:1

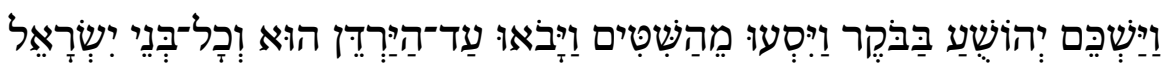

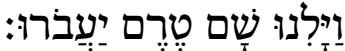

Joshua rose in the morning, and they set out from Shittim, and they came unto the Jordan, he and all the Israelites. They lodged there before crossing.

* Before they lodged there, they crossed.

If a native English speaker were to misread the temporal subordinator "before" (טֶרט) as relating to the preceding clause "they lodged there," BH instructors would most likely attribute it as a careless mistake. But such a mistake by a Cantonese speaker more likely results from a difficulty that stems

36 Of the 659 languages sampled by WALS (World Atlas of Language Structures Online), Cantonese is part of the 93 languages that display mixed usage with no position as dominant $(93 / 659 ; 14.1 \%)$. Initial subordinating conjunctions occur most frequently (398/659; 60.4\%); Dryer, "Order," http://wals.info/chapter/94.

37 Example from Matthews and Yip, Cantonese, 295.

38 For delimitative aspect; see note 24. Example from Matthews and Yip, Cantonese, 301. 
from the inherent disconnect between Cantonese and BH syntax in temporal clauses (i.e., final vs. initial temporal subordinators). However, a Cantonese student misreading a $\mathrm{BH}$ conditional clause is far less likely since both $\mathrm{BH}$ and Cantonese use initial conditional subordinators $(22,24)$. As a result, BH instructors will much better serve their non-native English speakers when they are sensitive to how subordinators for a given language can vary in their positions and may not be uniform in their usage of these positions.

\section{2b Causal Clauses (Before or after Main Clause)}

The second example of syntactic typology involves the causal clause, specifically the variable positions of the causal clause relative to the main clause. A language can potentially have the causal clause appear before or after the main clause (i.e., initial and final positions) or employ both positions. ${ }^{39} \mathrm{In}$ English and $\mathrm{BH}$, the causal clause employs both positions, ${ }^{40}$ but Cantonese only utilizes initial positions. ${ }^{41}$

(26) Because I was hungry, I ate the pie. (Initial Causal Clause)

(27) I ate the pie because I was hungry. (Final Causal Clause)

(28) Genesis 3:14a-d (Initial Causal Clause)

39 Holger Diessel and Katja Hetterle, "Causal Clauses: A Cross-Linguistic Investigation of Their Structure, Meaning, and Use," in Linguistic Universals and Language Variation, ed. Peter Siemund, TLing 231 (Berlin: De Gruyter Mouton, 2011), 28-31.

40 Whereas the clause introduced with $k \hat{\imath}$ usually appears after the main clause, the causal subordinator ya an usually introduces a clause which more often appears before the main clause (e.g., Num 20:12); Paul Joüon and Takamitsu Muraoka, $A$ Grammar of Biblical Hebrew, 2nd ed. (Rome: Gregorian and Biblical Press, 2011), $\S 170$.

41 Using Mandarin data in conversation and written texts as a test case, Song and Tao argue that in languages with both initial and final causal clauses, the initial clauses are for background information and final clauses are for mitigating potential disagreements or confusion that may arise with hearers or readers from the content of the main clause; see Zuoyan Song and Hongyin Tao, "A Unified Account of Causal Clause Sequences in Mandarin Chinese and Its Implications," StLang 33 (2009): 6975; While Cantonese does not employ a final position causal clause, it has a functional equivalent when the causal clause is the predicate in a sentence with a verb of being.

$\begin{array}{lllllll}\text { Ngóh gam faai góng yùhn haih yānwaih gón sìngaan. } \\ \text { I } & \text { so fast speak finish is because } & \text { short time. }\end{array}$

(The reason) I finished speaking so quickly is because time is short.

(Matthews and Yip are technically incorrect to offer this example as a causal clause following a main clause; Mathews and Yip, Cantonese, 298.) If this example is indeed comparable to a final causal clause, then it seems to corroborate Song and Tao's analysis in how final causal clauses are used to qualify a strong statement or evaluation. 
And the LORD God said to the serpent,

"Because you have done this, cursed are you from all the animals and from all the beasts of the field."

(29) Genesis 2:23a-e (Final Causal Clause)

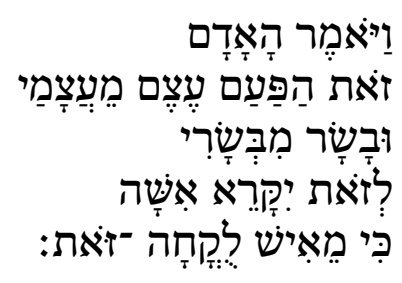

Then the man said,

"This at last is bone of my bones

and flesh of my flesh.

This one will be called woman

because from man this one was taken."

(30) Initial Causal Clause

Yānwaih ngóh ngòh ngóh sik-jo go bao

Because I hungry I ate CL bun.

Because I was hungry, I ate the bun.

(31) Final Causal Clause (Ungrammatical) ${ }^{42}$

*Ngóh sik-jo go bao yānwaih ngóh ngòh.

I ate CL bun because I hungry

*I ate the bun because I was hungry.

The following example illustrates the potential confusion that Cantonese speakers (in contrast to native English speakers) may have with BH causal clauses. The $k \hat{\imath}$ causal clause of line $9 \mathrm{~b}$ can be potentially read as subordinate to either line $9 \mathrm{a}$ or line 10a, but reading the causal clause as subordinate to line $9 \mathrm{a}$ is the sensible construal.

42 Interestingly, many American-born Chinese will form this type of ungrammatical structure with causal clauses, most probably on account of their dominant English syntax overriding the Cantonese syntax. 
Psalm 6:9-10

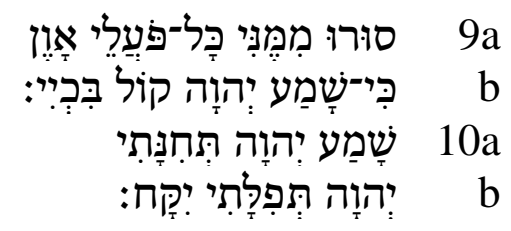

9a Turn away from me, $\mathrm{O}$ all workers of sin,

$\mathrm{b}$ because the LORD has heard the sound of my crying.

10a The LORD has heard my supplication.

b The LORD will take up my prayer.

9b *Because the LORD has heard the sound of my crying,

10a the LORD has heard my supplication.

Because both BH and English allow for causal clauses to come before or after a main clause, native English speakers will have less of a problem in identifying the correct subordination hierarchy for v. 9b. However, because Cantonese requires the subordinate causal clause to be placed before its main clause, it is easy to imagine how Cantonese students, with "hard-wired" Cantonese syntax conflating the developing BH syntax, ${ }^{43}$ may force the causal clause of v. $9 \mathrm{~b}$ to be read with v. 10a. While BH instructors and teaching grammars for English speakers will probably not have to explain how causal clauses can be in initial or final positions, $\mathrm{BH}$ instructors will likely profit from explicitly explaining the typological differences between causal clauses in $\mathrm{BH}$ and Cantonese.

\section{2c Relative Clauses (Head Initial and Head Final)}

The third and final example of syntactic typology demonstrates the syntactic variation in relative clauses. ${ }^{44}$ At a very broad level of categorization, dependent relative clauses can be head initial or head final. A head initial relative clause has the head noun (the modified nominal) precede the relative clause, and a head final relative clause has the head noun follow the relative clause. ${ }^{45}$ English and BH utilize head initial relative clauses.

43 For more concerning how native languages may affect the acquisition of a second language, see Naudé and Miller-Naudé, “A New Biblical,” 693-95.

44 For a comprehensive study of the BH relative clause that utilizes language typology, see Robert D. Holmstedt, The Relative Clause in Biblical Hebrew, LSAWS 10 (Winona Lake: Eisenbrauns, 2016).

45 This classification holds true only for external headed relative clauses as opposed to the relatively rare, internal headed relative clauses in which head nouns appear within the relative clauses; Jae Jung Song, Linguistic Typology: Morphology and Syntax (London: Routledge, 2001), 212-16. 
Chau, "Employing Language Typology," OTE 30/1 (2017): 56-76

(33) The people who raised me are my parents.

(34) Genesis 2:2a

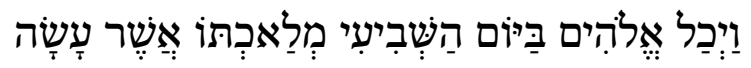

And God finished on the seventh day his work which he had done.

However, Cantonese utilizes head final relative clauses.

$$
\begin{aligned}
& \text { Sīk Gwóngdūng-wá ge hohksáang háau dāk hóu. }{ }^{46} \\
& \text { Know Cantonese that students examine ADV well } \\
& \text { The students who know Cantonese scored (on a test) well. }
\end{aligned}
$$

Because of the fundamental difference in how relative clauses are formed in Cantonese versus English and $\mathrm{BH}$, Cantonese students may have more difficulty understanding the $\mathrm{BH}$ construction. Thus in the following example of a dependent relative clause, Cantonese speakers may unconsciously revert to their native syntax and misread. ${ }^{47}$

(36) Isaiah 2:22a-b

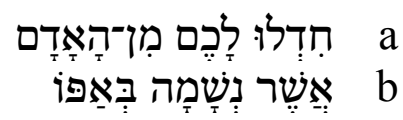

a Cease (for yourselves) from humanity,

b whose breath is in their nose

a $\quad *$ The breath in their nose

b that they ceased to you from humanity

For English speakers, identifying the head noun "humanity" (הָאָדָם) as immediately followed by the relative clause is quite normal since English and BH relative clauses are both head initial. But because Cantonese relative clauses are head final, Cantonese speakers may conceivably misidentify the head noun for the relative clause. They may misread "breath" (נְשׁמָה) as the head noun and all of the preceding line (a) as the relative clause.

On account of all these aforementioned examples of noncorrespondence in the syntactic typology of subordinate clauses in which the English and $\mathrm{BH}$ are similar but dissimilar to the Cantonese, BH instructors may

46 Example adapted from Matthews and Yip, Cantonese, 110.

47 Through a private conversation, Dr. Chloe Sun, who teaches Cantonese and Mandarin speakers, affirmed how this confusion does arise. (Mandarin like Cantonese also uses head final relative clauses.) She explained how she actually tells her students to translate these $\mathrm{BH}$ relative clauses straight into English in order to avoid the problem of the syntactic differences between Mandarin and Cantonese with $\mathrm{BH}$. 
greatly help non-native English speakers by asking the very simple questions as to how a respective BH subordinate clause is formed in one's native language: (1) position of the subordinator in clause, (2) position of subordinate clause with respect to main clause, and (3) position of relative clause with respect to head noun.

\section{CONCLUSION}

This comparison of BH to Cantonese has shown how aspects of a person's language may seem to be quite logically and naturally constructed but may be completely opposite in another person's native language. For example as shared previously, the English temporal subordinator "when" undoubtedly seems quite logical to native speakers as occurring at the beginning of the temporal clause since the "when" informs the hearer immediately that the following words are a temporal clause. However, as language typology has shown, many languages will have the reverse order of a temporal subordinator appearing at the end of the temporal clause. And for these speakers, this final subordinator will seem natural and logical to them. The following example illustrates the difficulty that English speakers may have when they are forced to jump back and forth between their natural syntax with initial subordinators and a recently learned syntax with final subordinators.

(37) Before I cooked the chicken, I washed it.

(38) I cooked the chicken before, I washed it.

Example (37) is the English construction for an initial temporal subordinator. But for example (38), imagine that this is the same sentence as (37) but constructed in a language with final temporal subordinators. Notice how the native syntax for English speakers disrupts the semantics of the construction (38). Examples (37) and (38) are supposed to be equivalent in meaning, but they are not immediately so because (38) is unduly difficult to process.

As stated earlier, this typological comparison of $\mathrm{BH}$ to Cantonese (and English) is not only intended to help teachers better tailor BH instruction to Cantonese speakers. These examples from Cantonese as a target language of instruction showcase Naudé and Miller-Naudé's original argument for the importance and value of language typology in teaching $\mathrm{BH}$ to students regardless of their native languages. ${ }^{48}$ This survey of language typology has purposely covered a wide range of language features from $\mathrm{BH}$ (question formation, verbal semantics, and clausal syntax) in order to show how language typology can be usefully applied across $\mathrm{BH}$ as a whole.

48 Naudé and Miller-Naudé, “A New Biblical,” 705. 
Admittedly most biblical scholars are not linguists or even language typologists, and initially it may seem quite daunting to use language typology. The following is a list of helpful remarks that will alleviate such concerns.

- Using language typology does not require instructors to know a multitude of languages. The research is presented with word-for-word translations and glosses that detail the specific linguistic features utilized (e.g., accusative case, gender, etc.). Moreover, not knowing the native language of one's student is not a significant obstacle. Fortunately, the World Atlas of Language Structures (wals.info) presents a free and userfriendly database of the world's many languages that provides typological details for a given language.

- While many BH instructors may not have access to formal instruction in language typology, there are numerous textbooks that are accessible for self-instruction (see bibliography).

- Because many BH instructors (especially those with postgraduate degrees) are already trained in Greek, Semitic languages, and European languages, they already possess a rich linguistic background that will allow them to more quickly comprehend the study of language typology. In other words, many $\mathrm{BH}$ instructors already have the linguistic "building blocks" for thinking about $\mathrm{BH}$ in terms of language typology.

\section{BIBLIOGRAPHY}

Chappell, Hilary. "On So Called Empty Particles in Yue-Guangzhou (Cantonese): A Study of Aspect." LTWPL 2 (1989): 91-112.

Comrie, Bernard. Language Universals and Linguistic Typology. 2nd ed. Chicago: The University of Chicago Press, 1989.

Cook, John. Time and the Biblical Hebrew Verb: The Expression of Tense, Aspect, and Modality in Biblical Hebrew. LSAWS 7. Winona Lake: Eisenbrauns, 2012.

Dahl, Östen. "Typology of Sentence Negation” Ling 17 (1979): 79-106.

Dayley, Jon P. Tzutujil Grammar. UCPL 107. Berkeley: University of California Press, 1985.

Diessel, Holger and Katja Hetterle. "Causal Clauses: A Cross-Linguistic Investigation of Their Structure, Meaning, and Use." Pages 23-54 in Linguistic Universals and Language Variation. Edited by Peter Siemund. TLing 231. Berlin: De Gruyter Mouton, 2011.

Dryer, Matthew S. "Definite Articles." In The World Atlas of Language Structures Online. Edited by Matthew S. Dryer and Martin Haspelmath. Leipzig: Max Planck Institute for Evolutionary Anthropology, 2013. http://wals.info/chapter/37. "Order of Adverbial Subordinator and Clause." In The World Atlas of Language Structures Online. Edited by Matthew S. Dryer and Martin Haspelmath. Leipzig: Max Planck Institute for Evolutionary Anthropology, 2013. http://wals.info/chapter/94. 
Greenstein, Edward L. "The Syntax of Saying 'Yes' in Biblical Hebrew." JANESCU 19 (1989): 51-59.

Holmstedt, Robert D. The Relative Clause in Biblical Hebrew. LSAWS 10. Winona Lake: Eisenbrauns, 2016.

Joosten, Jan. The Verbal System of Biblical Hebrew: A New Synthesis Elaborated on the Basis of Classical Prose. JBS 10. Jerusalem: Simor, Ltd., 2012.

Joüon, Paul and Takamitsu Muraoka. A Grammar of Biblical Hebrew. 2nd ed. Rome: Gregorian and Biblical Press, 2011.

Matthews, Stephen and Virginia Yip. Cantonese: A Comprehensive Grammar. London: Routledge, 2010.

Miller, Cynthia L. "Linguistics." Pages 657-69 in Dictionary of Old Testament: Historical Books. Edited by Bill T. Arnold and Hugh G. M. Williamson. Downers Grove, IL: Intervarsity Press.

Naudé, Jacobus A. and Cynthia L. Miller-Naudé. “A New Biblical Teaching Grammar for African Bible Translators: A Typological Approach.” OTE 24/3 (2011): 690-707.

Pope, Emily. "Questions and Answers in English." PhD Thesis, Massachusetts Institute of Technology, 1972.

Sadock, Jerrold M. and Arnold M. Zwicky. "Speech Act Distinction in Syntax." Pages 155-196 in Clause Structure. Edited by Timothy Shopen. Vol. 1 of Language Typology and Syntactic Description. 1st ed. Edited by Timothy Shopen. Cambridge: Cambridge University Press, 1985.

Song, Jae Jung. Linguistic Typology: Morphology and Syntax. London: Routledge, 2001.

Song, Jae Jung. The Oxford Handbook of Linguistic Typology. Oxford: Oxford Press, 2013.

Song, Zuoyan and Hongyin Tao. "A Unified Account of Causal Clause Sequences in Mandarin Chinese and Its Implications." StLang 33 (2009): 69-102.

Thompson, Sandra A., Robert E. Longacre, and Shin Ja J. Hwang. "Adverbial Clauses." Pages 237-300 in Complex Constructions. Edited by Timothy Shopen. Vol. 2 of Language Typology and Syntactic Description. Edited by Timothy Shopen. 2nd ed. Cambridge: Cambridge University Press, 2007.

Van der Merwe, Christo H. J., Jackie Naudé and Jan H. Kroeze. A Biblical Hebrew Reference Grammar. Sheffield: Sheffield Academic Press, 2006.

Whaley, Lindsay. Introduction to Typology: The Unity and Diversity of Language. Thousand Oaks: Sage Publications, 1997.

Waltke, Bruce K. and Michael P. O'Connor. An Introduction to Biblical Hebrew Syntax. Winona Lake, Ind.: Eisenbrauns, 1990.

Kevin Chau, Department of Hebrew, University of the Free State, Bloemfontein, South Africa. Email: kevindchau@gmail.com 